\title{
TKI-AINEISTOJEN AVARUUS - 3AMKIN AINEISTONHALLINNAN KÄYTÄNNÖT JA OSAAMINEN
}

Tiedontuotannon vastuullisuuden lisääminen on tällä hetkellä yksi eurooppalaisen tutkimus- ja innovaatiopolitiikan keskeisiä

pyrkimyksiä. Käytännössä tämä näkyy muun muassa siinä, että tutkimuksessa kerättävien aineistojen hallintaan kiinnitetään aiempaa enemmän huomiota. Monet rahoittajat edellyttävätkin hankehakemuksilta tutkimusaineiston tallentamista, jatkokäyttöä ja mahdollista jakamista pohtivaa aineistonhallintasuunnitelmaa. Ammattikorkeakouluissa aineistojen tallentamisen, jakamisen ja hyödyntämisen käytännöt ovat vasta kehittymässä.

Aineistonhallinta tutkimus-, kehittämis- ja innovaatiotoiminnassa

ineistonhallinnalla tarkoitetaan
sitä, että tutkimus-, kehittä-
mis- ja innovaatiotoiminnassa (TKI) muodostuvat aineistot (data) ja niihin liittyvä kuvaileva tieto (metatieto) on luotu, tallennettu ja järjestetty siten, että aineisto säilyy käyttökuntoisena ja luotettavana ja että tietosuoja ja tietoturva on varmistettu aineiston koko elinkaaren ajan (Aineistonhallinnan käsikirja 20I9). Aineiston käytettävyyteen liittyvät myös löydettävyys, saavutettavuus, yhdisteleminen, rikastaminen ja uudelleenkäyttö.

Aineistonhallinta on osa hyvää tieteellistä käytäntöä ja myös ammattikorkeakoulujen TKI-toiminnalta edellytetään aineistonhallinnan osaamista ja vakiintuneita käytäntöjä. Päkaupunkiseudun kolme ammattikorkeakoulua, Haaga-Helia, Laurea ja Metropolia (3АMK), ovat märitelleet yhteisessä Viisas avoimuus -politiikassa (2018) suuntaviivoja avoimuuden edistämiseen sekä aineistonhallinnan infrastruktuurien, ohjeistusten ja käytäntöjen kehittämiseen.

Kaikki kehitystyö edellyttää kuitenkin lähtötilanteen tuntemista, minkä vuoksi 3AMK toteutti kartoituksen aineistonhallinnan käytännöistä ja osaamisesta Viisas avoimuus - politiikan ollessa vielä työn alla. Tässä artikkelissa esittelemme kyselyn keskeiset tulokset ja pohdimme niiden perusteella aineistonhallinnan käytäntöjen kehittämisen lähtökohtia pääkaupunkiseudun kolmessa ammattikorkeakouluissa.

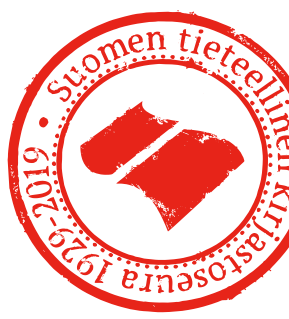


3AMKin aineistonhallinnan käytäntöjen ja osaamisen kartoitus

3AMкin keväällä 2018 tekemä kartoitus pohjautui kansainväliseen kyselyyn (2017) ja sen suomennokseen, jota tiivistettiin ja muokattiin ammattikorkeakoulujen TKI-toimintaan soveltuvaksi. 3АMK sai luvan hyödyntää ja muokata kyselyä suomennoksesta vastanneelta Oulun yliopiston Informaatiotutkimukselta ja kyselyn kansainvälisiltä tuottajilta (Enwald 20 I7). Muokattu kysely keskittyi aineistojen tallentamisen ja jakamisen käytäntöihin, minkä lisäksi siinä selvitettiin avattujen aineistojen hyödyntämistä sekä omien aineistojen löydettävyyden mahdollistamista.

Kansainvälisen kyselyn perusteella aineistonhallintakäytännöt ovat pääsääntöisesti vielä hajanaisia ja puutteellisia, joten myöskään 3AMkin käytäntöjen ei oletettu olevan kyselyn toteuttamisajankohtana kovinkaan kehittyneitä. Tarkoituksena onkin toteuttaa kartoitus muutaman vuoden kuluttua uudelleen, jolloin sen avulla voidaan todentaa politiikan ja kehittämistoimenpiteiden vaikuttavuus aineistonhallinnan käytäntöjen ja osaamisen kehittymisenä. Artikkelissa raportoituja tuloksia olisi kiinnostavaa verrata myös Aalto-yliopiston syksyllä 2018 toteuttamaan kyselyyn, joka suunnattiin kaikille ammattikorkeakouluille. Tämän kyselyn tuloksia ei ole vielä raportoitu.

3Амкin kyselyyn vastasi yhteensä
79 ammattikorkeakoulujen henkilökuntaan kuuluvaa ja yksi opiskelija. Vastaajista 32 oli Laureasta, 26 Metropoliasta ja 22 Haaga-Heliasta. Vastaajista kaksi kolmannesta toimi joko yhteiskuntatieteiden, liiketalouden ja hallinnon tai sosiaali-, terveys- ja liikunta-alan hankkeissa. Tässä analyysissa ei kuitenkaan pohdita niinkään vastausten ala- tai korkeakoulusidonnaisuutta vaan keskitytään yleisiin huomioihin aineistonhallinnan käytännöistä ja osaamisesta.

\section{TKI-aineistojen hankinta ja käyttö \\ yselyssä kartoitettiin aineistojen
hankintaa, käyttöä, tallentamis-
ta ja jakamista eri näkökulmista.} Sen ensimmäinen monivalintakysymys koski tutkimus- tai hankeaineistojen hankintaa (kuvio I). Kysymykseen vastanneista yli $90 \%$ kertoi hankkivansa tutkimus tai hankeaineistoa keräämällä itse uutta aineistoa. Lisäksi yli puolet ilmoitti käyttävänsä aiemmin keräämiään aineistoja. Muiden tuottamien aineistojen hyödyntämisen oli valinnut vain 34 vastaajaa, joista lähes puolet (I6) oli Metropoliasta.

Muiden tuottamien aineistojen osalta tulos ei ollut yksiselitteinen. Myöhemmin esitetyssä kysymyksessä vain I 5 vastajaa ilmoitti, ettei käytä muiden tuottamia aineistoja. Lisäksi kun tiedusteltiin avointen ja ei-avointen aineistojen hyödyntämistä, ilmoitti 57 vastajaa hyödyntävänsä avoimia aineistoja vähintään joskus. Ei-avoimia 


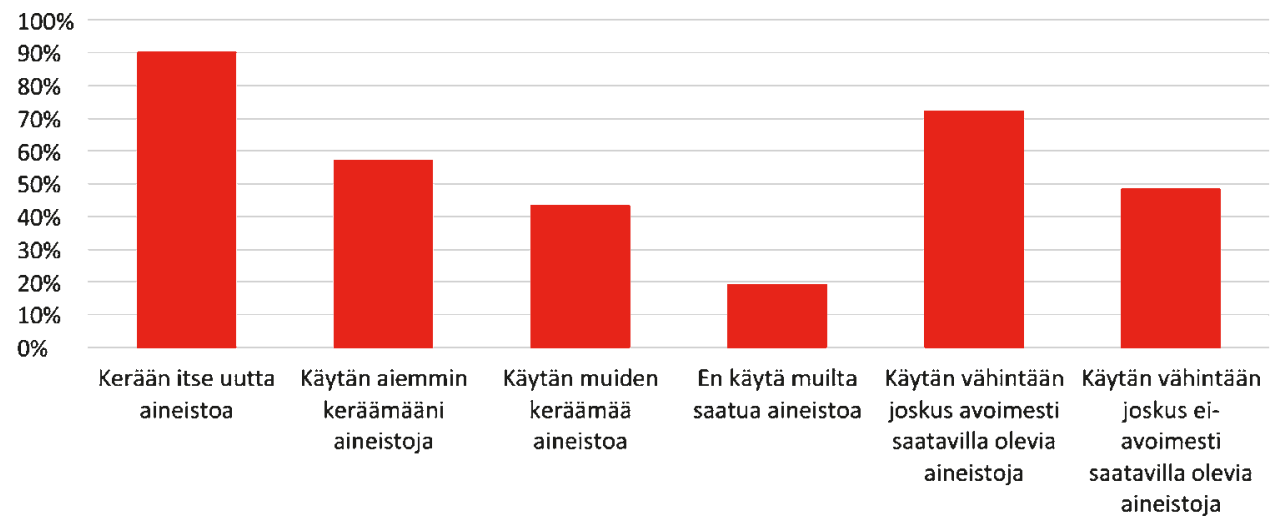

KUVIO 1. 3AMKin TKI-aineiston hankinta ja käyttö $(n=79)$

aineistoja ilmoitti niitäkin käyttävänsä 38 vastaajaa. Vastausten välinen ristiriita on huomattava.

Vaikka lähes kaikki TKI-toimijat keräävät omaa aineistoa, ei tämä suinkaan ole ainoa tapa hankkia tutkimus- tai hankeaineistoa. Jokainen tiedonkeruu on kuitenkin suunniteltu omista lähtökohdistaan, eikä valmis aineisto välttämättä huomioi kaikkia käynnissä olevan tutkimuksen kannalta tärkeitä seikkoja. Koska aineistojen avaamisen ja jakamisen yleistyminen saattaa lisätä valmiiden aineistojen käyttöä, haluttiin kyselyssä kartoittaa niiden muokkaamiseen vaadittavia resursseja.

Aineistojen muokkaustarvetta selvitettiin neliportaisella asteikolla, josta vastaaja saattoi valita kaikki tilannettaan kuvaavat vaihtoehdot. Vastausten perusteella osaa valmiista aineistoista voi käyttää ongelmitta sellaisenaan (I 6 vastausta). Toisen vaihtoehdon "käytän aineistoa hieman siistien/muokaten" oli valinnut 4I vastajaa ja yhtä moni vastaajia ilmoitti käyttävänsä huomatta-

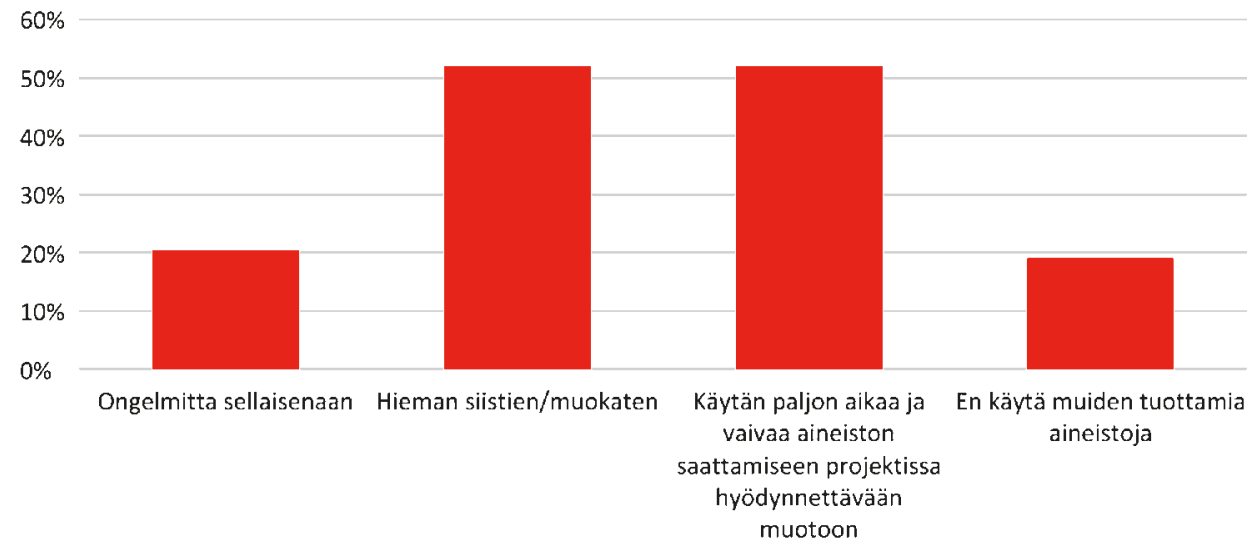

KUVIO 2. Muilta toimijoilta saatujen aineistojen muokkaaminen $(n=79)$ 
vasti aikaa aineistojen muokkaamiseen. Metropoliassa, jossa muiden tuottamia aineistoja käytettiin selvästi eniten, jopa $74 \%$ vastaajista ilmoitti käyttävänsä aineistojen muokkaamisen paljon aikaa ja vaivaa.

Kuvio 2 havainnollistaa muiden toimijoiden keräämien aineistojen muokkaamiseen käytettyä työmäärää. Vaihtelu on huomattavaa, ja olisikin kiinnostavaa selvittää työmäärään vaikuttavia tekijöitä.

\section{Aineistojen tallentaminen ja pitkäaikaissäilytys}

ineistonkeruu on usein työ-
lästä, ja monesti aineistoja ei
ehditä hyödyntämään kokonaisuudessaan. Aineistonhallinnan avulla voidaan luoda edellytyksiä aineistojen jatkokäytölle ja jakamiselle. Tämä puolestaan herättää kysymyksiä tutkittavien tietosuojasta sekä aineiston keränneiden toimijoiden oikeuksista. Yksi aineistonhallinnan tavoitteista onkin ohjeistaa TKI-toimijoita suun- nittelemaan etukäteen aineistonsa omistajuutta, pitkäaikaistallennusta, jakamista ja jatkokäyttöä.

Aineistojen jatkokäyttö- ja jakaminen edellyttävät aineistojen tallentamista tietosuojaltaan riittäviin yhteiskäytön mahdollistaviin tallennustiloihin. 3AMkin kyselyn perusteella aineistojen tyypillisin tallennuspaikka on edelleenkin oma tietokone, vaikka lähes yhtä usein aineisto oli tallennettu myös oman ammattikorkeakoulun verkkoasemalle. Pilvipalveluihin - joista eniten mainintoja keräsi Google Drive - aineistoja oli tallentanut yli puolet vastaajista, ulkopuoliseen tietoarkistoon puolestaan harvempi kuin joka kymmenes. Systemaattisia pitkäaikaistallennuksen käytänteitä ei 3AMkissa ollut, ja yksi vastaaja harmittelikin kotiorganisaationsa suhtautuvan dataan kertakäyttötavarana. TKI-aineiston tallentamiskäytäntöjä kuvataan kuviossa 3.

Oma laite

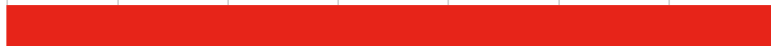

Ammattikorkakoulun verkkoasema

Pilvipalvelu

Ulkopuolinen tietoarkisto

Muu

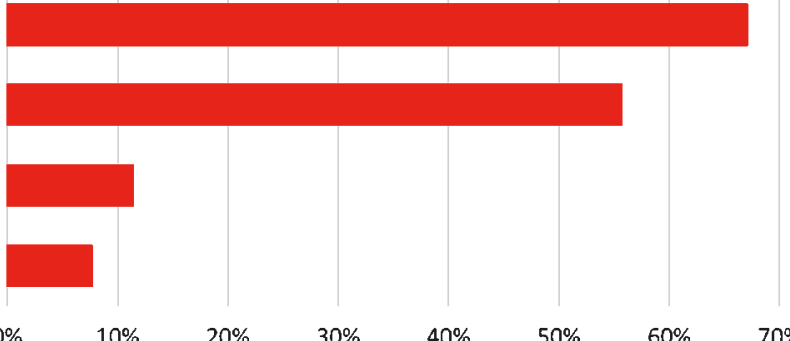


Aineiston tallennuspaikkoja mainittiin kyselyssä kaksinkertainen määrä vastaajiin nähden, joten useimmat aineistot ovat tallessa useammassa kuin yhdessä paikassa. Tätä voi pitää sekä suotavana - varmuuskopio aineistosta on hyvä olla olemassa - että ymmärrettävänä. Esimerkiksi pilvipalvelu voi olla hyvä tapa jakaa aineistoa mahdollisesti eri organisaatioissa työskentelevien hanketoimijoiden kesken, mutta aineiston analysointi ja käsittely edellyttävät usein aineiston tallentamista omalle koneella tai verkkoasemalle. Pitkäaikaissäilytyksen kannalta parhaina paikkoina vastaajat pitivät ammattikorkeakoulujen verkkoasemia.

Ammattikorkeakoulujen verkkoasemat eivät silti ole yksiselitteinen arkistointiratkaisu, sillä hankkeissa tuotetuilla aineistoilla voi olla monta omistajaa, jolloin kaikille aineiston omistajille tulisi taata yhtäläinen pääsy aineistoon myös hankkeen loputtua. Tähän tarkoitukseen ei affiliaatiosidonnainen verkkoasema sovellu. Toisaalta arkaluontoisten aineisto- jen kohdalla pitkäaikaistallennuksen tuottaman hyödyn ja aineiston säilyttämiseen mahdollisesti sisältyvien tietosuojariskien suhdetta on punnittava huolellisesti.

Yhden, kaikille aineistoille sopivan ratkaisun löytyminen on epätodennäköistä. Eri tilanteisiin soveltuvan tallennus- ja jakamisinfrastruktuurin sekä ohjeistuksen ja osaamisen kehittäminen edellyttääkin vielä paljon työtä. Aineistonhallinnan osalta ammattikorkeakoulujen suurin haaste onkin olettavasti juuri aineiston tallentamisen käytäntöjen kehittäminen ja myös omistajuudesta sopiminen.

\section{Aineistojen jakaminen}

Tarvittaviin tallennusratkaisuihin vaikuttavaa se keille ja miltä osin aineiston jakaminen koetaan tarpeelliseksi. Aineistojen jakamisen nykykäytänteitä sivuttiin kahdessa kysymyksessä, joista ensimmäisessä kysyttiin aineistojen jakamisesta ja toisessa pääsystä aineistoihin. Vastaukset erosivat toisistaan: siinä missä vain viisi vastaajaa ilmoitti, ettei jaa aineistojaan, kertoi I 8 vastajaa,

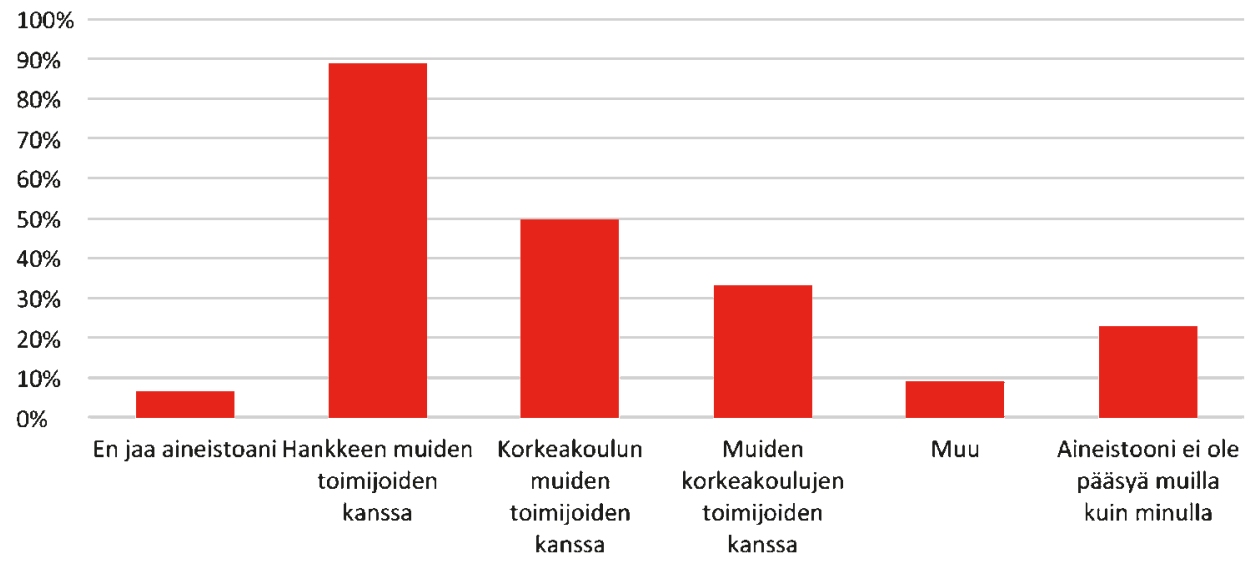

KUVIO 4. Oman aineiston jakaminen muiden kanssa $(n=79)$ 
ettei heidän aineistoonsa ole pääsyä kenelläkään muulla kuin heillä itsellään. Erojen pohjalta on perusteltua olettaa, ettei aineiston jakaminen ole yksiselitteisesti ymmärretty käytäntö.

Aineistoja jaetaan useimmiten hankkeiden sisällä (90\% vastanneista). Lisäksi oman korkeakoulunsa muiden toimijoiden kanssa aineistojaan jakoi noin puolet vastanneista ja toisten korkeakoulujen toimijoiden kanssa kolmannes. Pääsyä aineistoon kuitenkin rajoitettiin: täysin vapaasti aineistoaan jakoi vain joka neljäs ja hankkeiden sisälläkin aineistonsa antoi vapaaseen käyttöön vain $70 \%$ vastaajista. Rajatun pääsyn aineistoonsa salli hieman yli puolet vastanneista. Kuviossa $4 \mathrm{ku}$ vataan kerätyn aineiston jakamista eri toimijoiden kanssa.
Kyselyssä ei selvitetty tarkemmin, millaisia asioita aineistoista rajataan pois ennen niiden jakamista. Sen sijaan siinä tiedusteltiin aineistojen jakamiseen liittyviä huolia. Selkeästi eniten jakamisessa mietityttivät siihen liittyvät eettiset ja juridiset kysymykset, minkä lisäksi vastaajia huolettivat aineistojen väärät tulkinnat sekä sopivien toimintatapojen ja oikeuksien puute. Innovaatioetunsa menettämisestä oli huolissaan vain joka viides vastaaja ja noin kolmasosaa vastanneista ei aineistojen jakaminen huolettanut lainkaan (kuvio 5). Kaikki kolme yleisintä huolenaihetta sivuavat jossain määrin jakamisen eettisiä kysymyksiä, joten on mahdollista, että aineistojen jakamiseen tehdyt rajaukset liittyvät eettisesti kestävien toimintatapojen varmistamiseen.

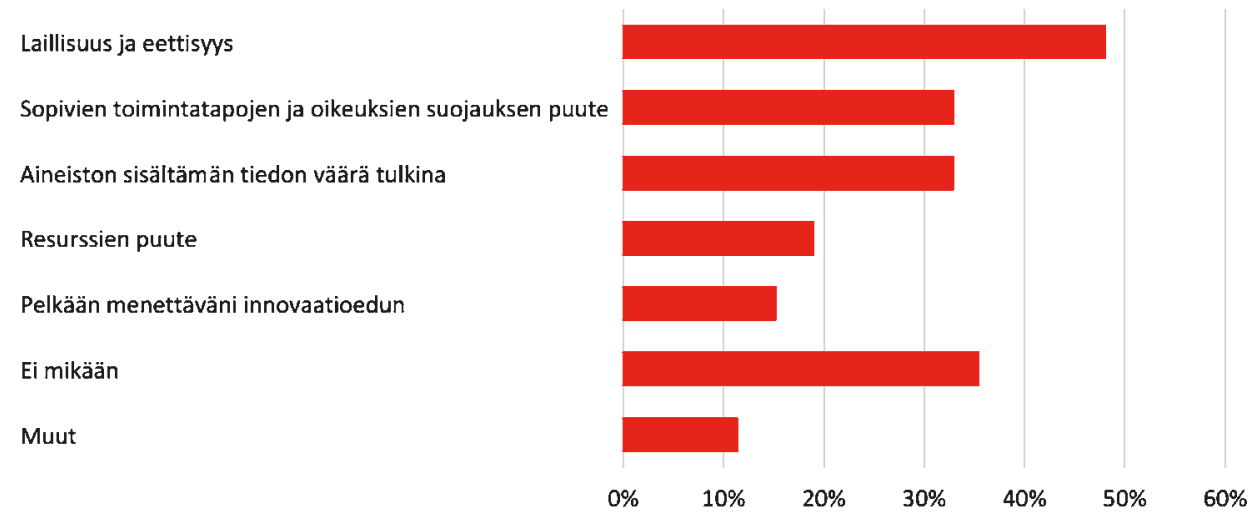

KUVIO 5. Koetut haasteet aineiston jakamisessa $(n=79)$ 
A ineistojen jakaminen perustuu nykytilanteessa ensisijaisesti hankeyhteistyöhön. Sen sijaan ajatus aineistoista yhteisenä kansallisena tai kansainvälisenä resurssina on mitä ilmeisimmin vielä harvinainen, sillä kyselyn perusteella vastaajat eivät olleet juurikaan pohtineet aineistojensa yleisempää saavutettavuutta ja löydettävyyttä. Vain puolet kyselyyn vastanneista kertoi liittävänsä aineistoonsa sen löytymistä helpottavia tietoja, kun taas kolmannes vastanneista ei lisännyt aineistoonsa lainkaan metatietoja. Aineiston jatkokäytön kannalta keskeisiä, tulkintaa tukevia kuvailevia metatietoja oli aineistoonsa lisännyt vain I $5 \%$ vastanneista. Tulokset ovat ymmärrettäviä suhteessa jakamiskäytäntöjen kehittämättömyyteen ja jakamiseen liittyviin huoliin.

\section{Aineistonhallintasuunnitelmas- ta apua}

Kyselyssä esitetyt kysymykset olivat samoja, joita aineistonhallintasuunnitelma ohjaa pohtimaan. Vastaajille ne olivat todennäköisesti uusia, sillä vain $30 \%$ vastaajista oli tietääkseen työskennellyt hankkeessa, jossa oli laadittu aineistonhallintasuunnitelma. Lisäksi vain viidennes vastaajista oli tietoinen organisaationsa käytössä olevista aineistonhallinnan työkaluista, mallisuunnitelmista tai ohjeistuksista. Kuitenkin puolet vastaajista uskoi aineistonhallintasuunnitelman auttavan aineistojen hallinnassa ja kolme neljästä vastaajasta ilmoitti olevansa kiinnostunut aineis- tonhallinnan koulutuksesta.

Kyselyn perusteella on selvää, ettei 3 AMKissa ollut keväällä 20 I 8 systemaattisia, kaikille yhteisiä aineistonhallintakäytäntöjä, vaan aineistojen jakamisen, tallentamisen ja metatietojen lisäämisen käytännöt vaihtelivat henkilöstä ja hankkeesta toiseen. Aineistoja uusiokäytettiin jonkun verran, mutta tällöinkin kyse oli useammin oman vanhan aineiston uusiokäytöstä kuin toisen tuottaman datan hyödyntämisestä, eikä omia aineistoja oikeastaan ajateltu yhteisinä resursseina. Silti toimijat olivat tietoisia aineistonhallintaan liittyvistä kiperistä kysymyksistä ja osasivat pohtia vastauksissaan aihetta niin hanketoimijoiden, organisaatioiden kuin tutkimuskohteidenkin kannalta.

Aineistojen systemaattisen pitkäaikaistallentamisen ja jakamisen mahdollistaminen edistäisivät aineistojen hyödyntämistä ja lisäisivät tutkimuksen läpinäkyvyyttä. Samalla on kuitenkin taattava tutkittavien tietosuoja ja riittävä ymmärrys aineiston käyttötarkoituksista sekä huolehdittava aineiston keränneiden toimijoiden oikeuksista. Eettiset ja juridiset kysymykset huolettavatkin TKI-toimijoita, ja aineistonhallinnan käytäntöihin ja ohjeistuksiin kaivataan selkeyttä. Yksi malli ei kuitenkaan sovi kaikkiin tapauksiin, joten ideaalitapauksessa aineistonhallintasuunnitelma toimii hanketoimijoiden eettisiä pohdintoja tukevana työkaluna, joka auttaa heitä miettimään aineiston säilyttämiseen, avaamiseen ja uusiokäyttöön liittyviä hyötyjä ja riskejä.

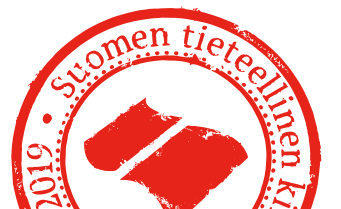


Vuonna 2017 toteutettuun kansainväliseen kyselyyn verrattuna 3AMKin aineistonhallinnan käytännöt ja osaaminen eivät vaikuttaneet sen kehittymättömimmiltä kuin muuallakaan maailmassa. Tutkijat ympäri maailmaa tunsivat heikosti organisaatioidensa ohjeistuksia ja mahdollisuuksia tutkimusaineistojen käyttöön, ja pitkäaikaistallentamisen käytännöt olivat vielä alkutekijöissään. Lisäksi tutkijat kokivat toisten tuottamien aineistojen hyödyntämisen haasteelliseksi ja omien aineistojen jakamisen arveluttavaksi. (ECIL 20I7). Valtionhallinto ja yliopistot tukevat Suomessa vahvasti tieteen avaamista, ja ammattikorkeakoulut seuraavat kehitystä tiiviisti soveltaen avoimuuden toimintakulttuuria TKI-toimintaansa. Lähtötilanteen tuntemus luo hyvän pohjan eettisen aineistonhallinnan kehittämiselle.

\section{Lähteet}

Aineistonhallinnan käsikirja, 2019. Tampere: Yhteiskuntatieteellinen tietoarkisto. www.fsd.uta.fi/aineistonhallinta/fi/. Viitattu I0.7.2019

ECIL 2017. European Conference on Information Literature. I 8-21.9.20I7 St Malo. www.ecil2017.ilconf.org/Viitattu 10.7.2019.

ENwald, H. 2017. Yksityinen sähköposti Hanna Lahtiselle I6.10.2017.

Aho, H.-R.; Lahtinen, H. \& Hakala, H. 2017. ecil 2017: Vuoroveden voimaa, uusia ajatuksia ja hedelmällistä yhteistyötä. Kreodi 3. https://www.kreodi.fi/en/22/ Matkakertomuksia/4I 4/ECIL-20 I7-vuoroveden-voimaa-uusia-ajatuksia-ja-hedelmällistäyhteistyötä.htm. Viitattu 10.7.20I9

Viisas avoimuus, 2018. 3AMkin yhteiset avoimuuden lupaukset ja periaatteet.

Helsinki: Haaga-Helia Амк, Laurea AMK ja Metropolia AMK. https://libguides.laurea.fi/ ld.php?content_id=31703189. Viitattu I0.7.2019

\section{Tietoa kirjoittajista}

\author{
Maija MerimaA \\ Suunnittelija \\ tieto- ja julkaisupalvelut \\ Laurea-ammattikorkeakoulu \\ maija.merimaa@laurea.fi
}

\author{
HanNa LaHTinen \\ Johtaja \\ tieto- ja julkaisupalvelut \\ Laurea-ammattikorkeakoulu \\ hanna.lahtinen@laurea.fi
}

